DOI: $10.5613 /$ rzs.45.1.6

\section{Alistair Ross}

\section{Understanding the Constructions of Identities by Young New Europeans: Kaleidoscopic selves}

Abingdon, Oxon - New York:

Routledge, 2015, 217 str.

Knjiga A. Rossa Understanding the Constructions of Identities by Young New Europeans: Kaleidoscopic selves nastala je na osnovi empirijskog istraživanja provedenog između siječnja 2010. i listopada 2012. godine u 15 europskih zemalja. U tom je razdoblju autor, profesor emeritus obrazovnih znanosti na Londonskom Metropolitan sveučilištu i Jean Monnet profesor građanskog obrazovanja u Europi, razgovarao $\mathrm{s}$ ukupno 974 mladih u dobi između 11 i 19 godina iz 97 škola te u sklopu 159 fokusnih grupa. Zemlje obuhvaćene istraživanjem bile su Bugarska, Cipar, Češka Republika, Estonija, Mađarska, Latvija, Litva, Poljska, Rumunjska, Slovačka i Slovenija, države koje su pristupile Europskoj uniji između 2004. i 2008., te Hrvatska, Island, Makedonija i Turska, države koje su 2012. bile u statusu zemalja kandidata za ulazak u EU. Taj odabir zemalja u izravnoj je vezi s glavnom temom knjige, odnosno pitanjem kako mladi konstruiraju svoje identitete - kao građani svojih zemalja ili kao (budući) građani EU-a, tj. unutar nacionalnog ili širega europskog prostora. Autor pritom polazi od pretpostavke da razmjerno svježe iskustvo pristupanja Europskoj uniji, zajedno s postkomunističkim naslijeđem većine zemalja u kojima je provedeno istraživanje »potiče građane i one koji prebivaju u tim zemljama na refleksiju o svom nacionalnom pripadanju i o osjećaju pripadnosti Europskoj uniji« (str. 186).

Knjiga je podijeljena na opći uvodni dio te na četiri tematska dijela $\mathrm{u}$ kojima se obrađuju različiti aspekti izgradnje identiteta mladih: Konceptualiziranje identiteta, Nacionalni identiteti, Europski identiteti i Kontingentni identiteti. U spomenutim se razmatranjima identiteti u osnovi konceptualiziraju kao društveno izgrađeni osobni narativi (eng. self-narratives). To je razumijevanje blisko S. Hallu (str. 10) i drugim »konstruktivistima« koji odbacuju svako esencijalističko razumijevanje grupne pripadnosti te identitete promatraju ponajprije kao diskurzivno konstruirane kulturne artefakte. Uz naglašeno diskurzivni karakter razumijevanja identiteta u ovome istraživanju veže se i odabir metodologije za prikupljanje podataka. Prema autorovu mišljenju, društvena konstrukcija identitetskih narativa (tj. činjenica da se identitetski konstrukti izgrađuju kroz interakciju u društvenim kontekstima) čini fokusnu grupu optimalnim istraživačkim alatom koji dopušta da se kroz raspravu »čuje« specifični grupni diskurs, dok se istodobno smanjuje potreba istraživača za potencijalno izobličavajućim intervencijama (str. 31). U dijelu posvećenom metodološkim pitanjima, autor također propituje subjektivnost kvalitativnih 
istraživanja što ih izvodi samo jedan istraživač. Kao svojevrsni »korektiv«, uvodi refleksiju vlastitog identiteta putem koje prolazi kroz najvažnije momente svoje privatne biografije (obiteljsko podrijetlo, generacijska pripadnost i dr.) i one profesionalne, u sklopu čega detaljno obrazlaže pozadinu, nastanak i provedbu studije (primjerice, tematska težišta fokusnih grupa koja reflektiraju autorove vrijednosti i interese).

Osnovni teorijski okvir Rossove studije čine tri analitičke dimenzije: 1) razlikovanje kulturnih i građanskih komponenti u izgradnji identiteta unutar političkih zajednica (prema M. Bruteru); 2) relativna razina entuzijazma ili indiferentnosti za nacionalne i/ili europske identitete (prema L. Jamieson); 3) (ne)postojanje razlika između generacijskih kohorti u vezanosti za nacionalni i/ili europski identitet (prema M. Fulbrook). Prolazeći kroz svaku od navedenih analitičkih »osi«, autor prezentira zajedničke obrasce i teme, kao i nacionalne $\mathrm{i}$ regionalne razlike.

Većina mladih s kojima je autor razgovarao nacionalni identitet razumije kao određenu primordijalnu datost koju povezuju s kulturnim naslijeđem, jezikom, kulturnim praksama, ali i prirodnim karakteristikama pojedinih zemalja. Pritom se, primjerice, jezik kao označitelj nacionalnog identiteta više ističe u manjim zemljama (npr. Latvija, Mađarska, Slovačka), dok se takva uloga jezika manje spominje u zemljama s većim brojem stanovnika (npr. Turska, Poljska, Rumunjska). Razmjerno rijetki negativni stavovi prema nacionalnom kulturnom naslijeđu vežu se uglavnom uz tzv. »balkanski mentalitet«, koji se nerijetko doživljava kao antimoderan i društveno nepogodan. Dok kulturnu komponentu nacionalnog identiteta prožimaju snažna i vrlo diferencirana iskustva, građanska je komponenta potisnuta i po pravilu se ne doživljava kao element pozitivne nacionalne identifikacije. Nadalje, za opis činjenice da mladi ne vide mogućnost relevantne političke participacije, autor se koristi sintagmom o naciji kao političkom vakuumu (eng. the nation as a political vacuum), koja upućuje na razočaranost i nepovjerenje mladih prema etabliranim političkim strukturama. Studija je pokazala da ta situacija po pravilu izaziva osjećaj nemoći i razočaranja, pri čemu samo manji dio mladih izražava spremnost za sudjelovanje u političkim promjenama. No, zanimljivo je da se ta, uglavnom kulturna, koncepcija nacionalnoga ne manifestira u obliku (očekivane) etnonacionalne isključivosti. Uzevši u cjelini, opisano viđenje vlastite nacije češće proizvodi osjećaj dobroćudne patriotske vezanosti (eng. benign patriotic affection), a rjeđe strastvenu predanost (eng. passionate commitment) zemlji, odnosno naciji. U tom je smislu, prema mišljenju mladih s kojima se razgovaralo, došlo do generacijskog pomaka i do svjesnog distanciranja od nacionalističkog sentimenta karakterističnog za generaciju roditelja i generacije prije njih.

$\mathrm{S}$ druge strane, kad je riječ o europskom identitetu i s njim povezanim narativima, građanska se komponenta pokazuje značajnijom od zajedničkih 
(nadnacionalnih) kulturnih konstrukata. Točnije, mladi doživljavaju zajednički europski prostor ponajprije instrumentalno, kao prostor koji omogućuje slobodu kretanja i mogućnost studiranja i rada u drugim europskim zemljama. Osim toga, mladi prepoznaju važnost europskih institucija i njihovu ulogu u poticanju ekonomskog razvoja, očuvanju zajedničke sigurnosti i brizi za ljudska prava. Za razliku od pozitivne instrumentalne identifikacije $\mathrm{s}$ Europom, u emocionalnom smislu europski identitet mladih ostaje u mnogočemu nedorečen i proturječan: od tvrdnji o nepostojanju distinktne europske kulture i svođenja Europe na puki geografski pojam, do percipiranja Europe i njezine kulture kao (još uvijek) nedostižnog ideala $\mathrm{i} /$ ili nejasne prijetnje koja potkopava lokalne/nacionalne identitete. Sukladno tomu, autor naglašava da je većina mladih imala problem pri izdvajanju bilo koje specifično europske kulturne karakteristike s kojom bi se mogli identificirati. Ta se neodređena percepcija europske kulture donekle promijenila tek pri razmatranju Turske $\mathrm{i} / \mathrm{ili}$ Rusije kao potencijalnih članica EU-a. Autor ističe da europska kultura stječe neke zajedničke nadnacionalne konture tek u usporedbi s tim dvjema (u odnosu na Europu) geografski i kulturno »rubnim« nacijama.

Ovdje prikazani elementi iz razgovora koje je autor studije vodio u različitim (istočno)europskim zemljama protive se predodžbi o »privatiziranoj« generaciji mladih nezainteresiranoj za šira društvena zbivanja: mladi ljudi $\mathrm{s}$ kojima se razgovaralo zastupaju informirana stajališta o različitim aspektima društvenog života, i uz pomoć tih stajališta izgrađuju novi, specifični tip identiteta u kojem ima mjesta i za tradicionalnu nacionalnu i utilitarnu europsku komponentu. Kako bi što plastičnije opisao način na koji mladi konstruiraju svoje identitete, Ross koristi sliku kaleidoskopa, odnosno, koncept kaleidoskopskih identiteta. To znači da za razliku od autora koji naglašavaju ponajprije nepostojanost i fluidnost identiteta u kasnoj modernosti (npr. Z. Bauman i A. Giddens), Ross u fokus stavlja supostojanje mnogobrojnih identitetskih perspektiva, od kojih svaka za sebe tvori specifičan obrazac koji uključuje niz koherentnih iskustava i uvjerenja. Jedan od ključnih momenata u toj kaleidoskopskoj izmjeni perspektiva svakako predstavlja gore spomenuta izmjena europskog i nacionalnog, pri čemu prema mišljenju autora, tradicionalno zgusnuta sjena nacionalnog identiteta, $u$ »suživotu « s onim europskim, ipak postaje donekle transparentnijom.

Knjiga A. Rossa Understanding the Constructions of Identities by Young New Europeans: Kaleidoscopic selves predstavlja kompetentan i inventivan doprinos razumijevanju identiteta mladih u suvremenoj Europi i, što je posebno vrijedno, potiče stručnu i širu javnost na razmišljanje o toj društveno važnoj i sadržajno kompleksnoj tematici.

Saša Puzić

Institut za društvena istraživanja u Zagrebu 